\title{
A pilot plant study using ceramic membrane microfiltration, carbon adsorption and reverse osmosis to treat CMP (chemical mechanical polishing) wastewater
}

\author{
R. Lo* and S.-L. Lo** \\ *Vivendi Water Systems Taiwan Corporation, 4F, No.14, Lane 609, Sec.5, Chung-Shin Rd., Sanchung, \\ Taipei County, Chinese Taiwan (E-mail: robinson.lo@vivendiwater.com) \\ **Graduate Institute of Environmental Engineering, National Taiwan University, 71 Chou-Shan Rd., Taipei \\ 106, Chinese Taiwan (E-mail: s/lo@ccms.ntu.edu.tw)
}

\begin{abstract}
Currently, most semi-conductor plants adopt the conventional chemical coagulation and sedimentation process to treat chemical mechanical polishing (CMP) wastewater. This treatment process consumes a large quantity of coagulants, and its optimum $\mathrm{pH}$ operation range is rather narrow. This treatment process produces huge amounts of sludge and is hard to operate due to the unstable characteristics of the abrasive slurry of CMP wastewater. The purpose of this research is to establish a pilot plant which consists of chemical pretreatment, ceramic membrane microfiltration, carbon filtration and reverse osmosis system, which will allow the reclamation of the CMP wastewater. Actual CMP wastewater was sampled and treated in the pilot plant. The results of the pilot tests demonstrated the viability of the treatment scheme and provided data for scale-up calculations. Cost per ton of CMP wastewater reclaimed was calculated using the operating data established, and compared with the conventional chemical coagulation and sedimentation process.
\end{abstract}

Keywords Ceramic membrane microfiltration; chemical mechanical polishing (CMP); ultra pure water

\section{Introduction}

Chemical mechanical polishing (CMP) is a process which smoothens the wafer surface in semiconductor manufacturing; it is also called chemical mechanical planarization. It is the latest and most popular technology in integrated circuit processing. In the polishing process, a large quantity of ultra pure water (UPW) is needed to flush out residual suspended solids, or heavy metal contaminants, that are left on the wafer surface after the abrasive procedure. Therefore, CMP wastewater refers to the contaminated water collected at the end of rinse processes. According to statistics, CMP wastewater makes up $15-25 \%$ of the total wastewater discharged from semiconductor manufacturing processes. With increasing production in semiconductors, and due to the existence of different CMP processes and different chemicals used by companies, more and more different CMP wastewater of different characteristics are produced each year.

In the past, chemical clarification was the dominant method for treating CMP wastewater. The treated water was normally discharged without considering wastewater reclamation. One of the shortcomings of the chemical clarification process is that the treated CMP wastewater often retains a high concentration of suspended fine particles, which means the effluent water is usually high in turbidity and suspended solids. The troublesome selection of coagulants and different system $\mathrm{pH}$ levels also add to the difficulty of the treatment operation. Although microfiltration (MF) systems have recently been used to recover filtered water for cooling towers' make up, scrubber washing or general rinse usage, the reuse application for the recovered water is still limited. If the recovered water can be treated further, and improve its water quality to meet the ultra pure water system's make up, it would then become a valuable resource. 
This pilot test plant used chemical coagulation with low-sludge generating polymer for pretreatment. The system $\mathrm{pH}$ was maintained in 3.5-4.0 range, since this condition would lower the zeta potential of particles and electroneutralize the charges of each particle. After destabilizing, the microparticles flocculated and grew to a size bigger than $0.2 \mu \mathrm{m}$, which can be easily removed by ceramic membrane filter. This pilot test also compiled operation data from laboratory pretests, like jar tests to establish the best coagulation conditions, and activated carbon adsorption tests to calculate the flow velocity, the filling depth of activated carbon, and the contact time. Therefore, this pilot plant was set up based on the combination of laboratory pretests' results and engineering experiences. This pilot plant uses CMP wastewater from an existing semiconductor plant. The data from pilot plant tests were scaled up to simulate an actual manufacturing plant after the optimum operating conditions were established. Operation cost of CMP wastewater reclamation was estimated and compared with operation cost of the traditional chemical clarification system. This may provide some valuable operation parameters and cost estimates for future research reference.

\section{Properties of CMP wastewater}

In general, waste slurry from CMP process can be categorized into oxidants and metal abrasion slurry, and contains the following chemicals:

Abrasion: $\mathrm{SiO}_{2}, \mathrm{Al}_{2} \mathrm{O}_{3}, \mathrm{CeO}_{2}, \mathrm{ZrO}_{2}$. pH buffer solution: $\mathrm{KOH}, \mathrm{NH}_{4} \mathrm{OH}, \mathrm{HNO}_{3}$ or organic acids.

Oxidants: $\mathrm{H}_{2} \mathrm{O}_{2}, \mathrm{Fe}\left(\mathrm{NO}_{3}\right)_{3}, \mathrm{KIO}_{3}, \mathrm{Fe}(\mathrm{KCN})_{3}$.

Etching materials: $\mathrm{SiO}_{2}, \mathrm{~W}, \mathrm{Al}, \mathrm{Cu}, \mathrm{Na}, \mathrm{K}, \mathrm{Ni}, \mathrm{Fe}, \mathrm{Zn}$.

Other agents: Surfactants, chelating agents, corrosion inhibitors.

The above chemicals found in abrasion slurry and rinse steps in CMP process contain high levels of suspended solids, $\mathrm{SiO}_{2}$, and a small quantity of $\mathrm{H}_{2} \mathrm{O}_{2}$ and heavy metals. In this study, CMP wastewater which contains oxide and metal slurry with rinse water from an existing semiconductor company was tested. The mixture of CMP wastewater quality was analyzed as shown in Table 1.

\section{Applied technologies for CMP wastewater}

Current CMP wastewater treating processes can be classified into two categories:

- implement chemical coagulation as a pretreatment, and add gravity sedimentation, air dissolved flotation, or membrane filtration processes;

- without dosing any chemicals for the precoagulation, but direct treatment using ultrafiltration (UF), electrocoagulation/electrodecantation (EC/ED), or through applying an external electric field to the microfiltration systems.

Table 1 CMP wastewater quality

\begin{tabular}{ll}
\hline Water quality items & Value \\
\hline $\mathrm{pH}$ & $9.5-10$ \\
$\mathrm{Conductivity}(\mu \mathrm{s} / \mathrm{cm})$ & $65-180$ \\
$\mathrm{TOC}(\mathrm{mg} / \mathrm{L})$ & $2-5$ \\
$\mathrm{SiO}(\mathrm{mg} / \mathrm{L})$ & $98-224$ \\
$\mathrm{TSS}(\mathrm{mg} / \mathrm{L})(>1.6 \mu \mathrm{m})$ & $3.6-6.2$ \\
$\mathrm{TDS}(\mathrm{mg} / \mathrm{L})$ & $72.5-116.7$ \\
$\mathrm{H}_{2} \mathrm{O}_{2}(\mathrm{mg} / \mathrm{L})$ & $14-42$ \\
$\mathrm{Al}(\mathrm{mg} / \mathrm{L})$ & $0.013-11.8$ \\
$\mathrm{~W}(\mathrm{mg} / \mathrm{L})$ & $2.8-6.0$ \\
\hline
\end{tabular}


Coagulation and flocculation are effective, commonly used chemical processes that involve neutralization of ion and particle surface charge using oppositely charged inorganic materials. This procedure alone may be enough to destabilize some soluble organics, heavy metals and suspended materials, so that they can be filtered or isolated by other units.

Gravity settling is a simple and proven technology, which is space demanding. Due to the high concentration of suspended solids in CMP waste slurry, Lin et al. (1999) used a flotation column to separate abrasion slurry effectively. Better removal efficiency can be achieved by adding a catch-up agent into the system and controlling dissolved air pressure.

Compared to gravity clarification systems, cross-flow membrane microfiltration systems are more effective in removal of solids and have smaller system footprint. Cross-flow filtration uses tangential water flow through an array of ceramic tube filters, or multilayer polymer sandwiches, to remove suspended solids and other contaminants. Water enters the tube at a pressure ranging from 25 to $75 \mathrm{psi}$, and is partitioned into water that permeates the tube (filtered) and reuses water that passes straight through the tubes (unfiltered). Crossflow flux values range from 10 to 150 GFD. The use of these systems in CMP wastewater treatment has been reviewed. Suppliers of cross-flow filtration systems include EPOC Filtration, Pall Corp and US Filter.

Microbar recently introduced a new filtration technology, single-pass membrane array system (or EnChem system). The flux capacity exceeds 200 GFD. This system can operate at low pressure (4-10 psi) and high flow rate (to 5,000 gal/min). Unlike cross-flow filtration, the EnChem system processes wastewater in a single pass with non-recirculation mode.

\section{Direct use of ultrafiltration and electrocoagulation treatment systems}

Recently, some new approaches have been investigated for particle destabilization in CMP wastewater without adding of chemicals. Pall owns Microza ultrafiltration modules technology. It is a two-layer hollow fiber organic membranes with molecular weight cut off (MWCO) at 10,000 daltons.

Mettson et al. (1995) used electrolysis to increase ions in wastewater, and then proceed with electrocoagulation to effectively remove microparticles. Raghavan (1999) used electrocoagulation / electrodecantation technology to treat CMP wastewater in semiconductor industry. Golden et al. (2000) applied electric fields to destabilize the microparticles in CMP wastewater, and the CMP wastewater is treated by moving the charged silicate particles together and then go through the microfiltration. Yang and Yang (2002) used external electric fields along with microfiltration to treat CMP wastewater. They found that the treating capacity could be increased. The treated water was analysed to be non-turbid, and can easily be recovered and reused.

\section{Experimental methods and equipments}

This pilot test plant used ceramic membrane filtration system combined with coagulation pretreatment, by simply adding polymers as a coagulant. The coagulated particle size is a

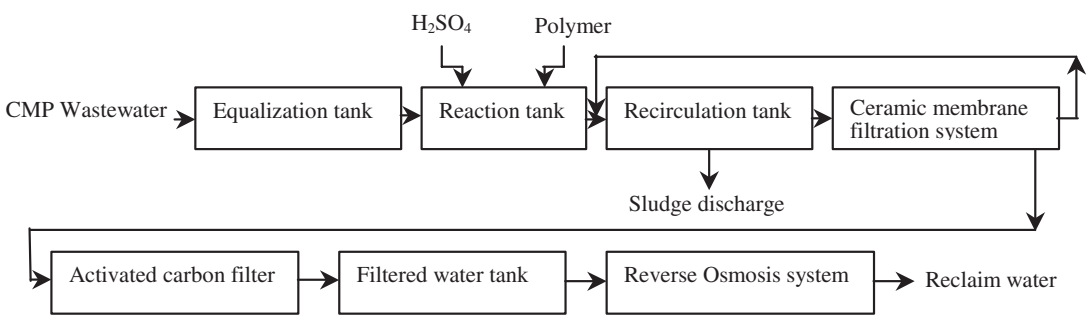

Figure 1 Flow diagram of the pilot plant 


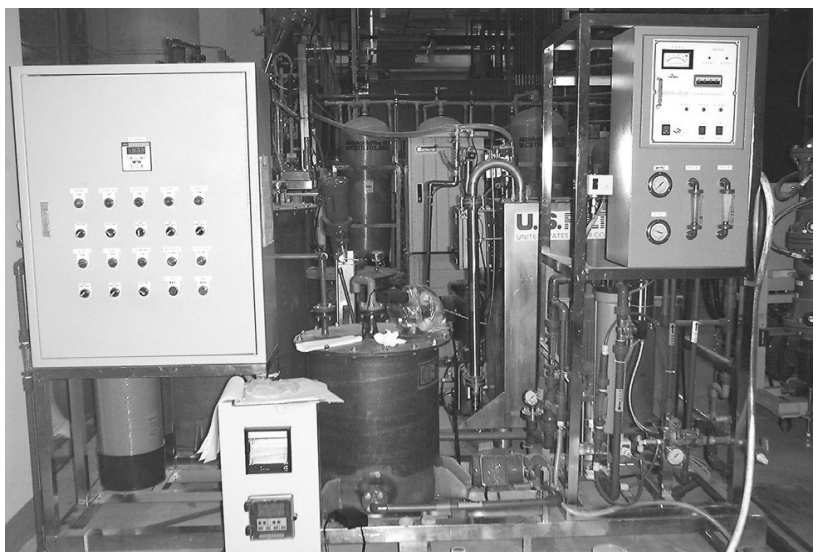

Figure 2 Front view of the pilot plant

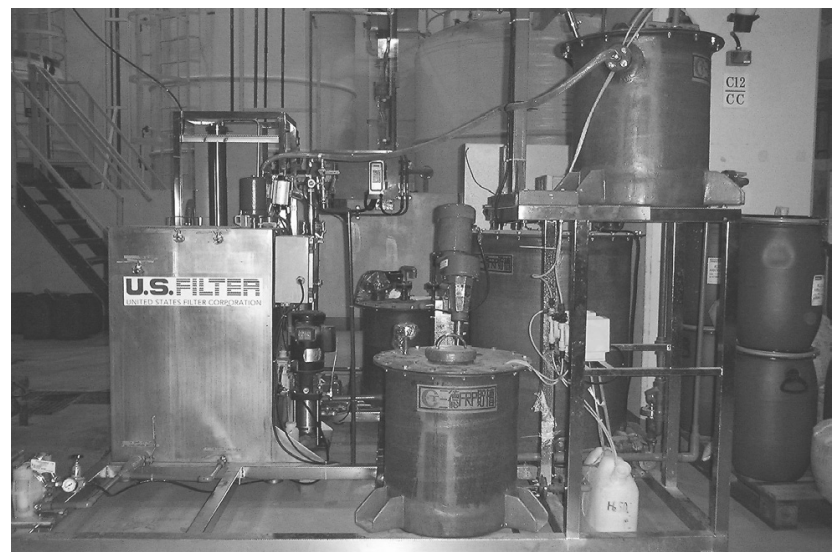

Figure 3 Back view of the pilot plant

Table 2 Operation conditions for pilot plant tests

\begin{tabular}{|c|c|c|}
\hline Unit equipment & Operation conditions & \\
\hline Equalization tank & $\begin{array}{l}\text { Inlet flow (L/min) } \\
\text { Retention time (min) }\end{array}$ & $\begin{array}{l}4.0 \\
100\end{array}$ \\
\hline Reaction tank & $\begin{array}{l}\text { Reaction time }(\mathrm{min}) \\
\text { Mixer speed }(\mathrm{rpm}) \\
\mathrm{H}_{2} \mathrm{SO}_{4} \text { dose }(\mathrm{mg} / \mathrm{L}) \\
\text { Polymer dose }(\mathrm{mg} / \mathrm{L})\end{array}$ & $\begin{array}{l}20 \\
180 \\
6000 \\
16\end{array}$ \\
\hline Ceramic membrane filtration system & $\begin{array}{l}\text { Inlet pressure }\left(\mathrm{kg} / \mathrm{cm}^{2}\right) \\
\text { Permeate water flow }(\mathrm{L} / \mathrm{min}) \\
\text { Flux }\left(\mathrm{L} / \mathrm{hr} / \mathrm{m}^{2}\right) \\
\text { Sludge discharge }(\mathrm{L} / \mathrm{min})\end{array}$ & $\begin{array}{l}2.5 \\
2.6-3.4 \\
520-680 \\
4.3\end{array}$ \\
\hline Activated carbon filter & $\begin{array}{l}\text { Inlet flow }(\mathrm{L} / \mathrm{min}) \\
\text { Contact time }(\mathrm{min}) \\
\text { Linear velocity }(\mathrm{m} / \mathrm{hr}) \\
\text { Filter media depth }(\mathrm{cm})\end{array}$ & $\begin{array}{l}2.6-3.4 \\
8.3-11 \\
5-6.5 \\
90\end{array}$ \\
\hline Reverse osmosis system & $\begin{array}{l}\text { Inlet flow }(\mathrm{L} / \mathrm{min}) \\
\text { RO recovery rate }(\%) \\
\text { Permeate water flow }(\mathrm{L} / \mathrm{min}) \\
\text { Concentrate water flow }(\mathrm{L} / \mathrm{min})\end{array}$ & $\begin{array}{l}3.5-4.0 \\
75 \\
2.6-3.1 \\
0.9-1.0\end{array}$ \\
\hline Chemical dosing system & $\begin{array}{l}\mathrm{H}_{2} \mathrm{SO}_{4}(\%) \\
\text { Polymer }(\%) \\
\mathrm{H}_{2} \mathrm{SO}_{4}(\mathrm{~mL} / \mathrm{min}) \\
\text { Polymer }(\mathrm{mL} / \mathrm{min})\end{array}$ & $\begin{array}{l}36 \\
0.2 \\
32 \\
36\end{array}$ \\
\hline
\end{tabular}


little bit bigger than $0.2 \mu \mathrm{m}$, which would be large enough for ceramic membrane to efficiently remove. Activated carbon filtration and reverse osmosis system were set up in the down stream of ceramic filtration to further treat the filtered water, hence provide better quality reclaim water to meet with the reuse requirement. Figure 1 shows the flow diagram of this pilot plant, and the equipment systems was arranged as shown in Figures 2 and 3.

Table 2 shows the operation conditions for pilot plant tests. Based on the properties of CMP wastewater, the contaminants to be removed from pretreatment system, and the predefined water quality of reclaimed water, operating conditions were defined for the pilot plant tests. Table 3 shows the sampling points, analytical items and sampling frequency for analysis. Most of them are tested by potable instruments on site, and some are delivered to the laboratory for analysis. Table 4 indicates the analytical instruments or methods used during the test period.

The main equipments and specifications are as follows:

- equalization tank: 500 litres, material FRP.

- reaction tank: 100 litres, material FRP, with mixer.

- recirculation tank: 100 litres, material stainless steel.

- ceramic membrane filtration system: Recirculation pump (150 L/min) $0.2 \mu \mathrm{m}$ ceramic membrane filter (US Filter product), air operated diaphragm pump $(15 \mathrm{~L} / \mathrm{min}$ ).

- activated carbon filter: Dia. $200 \mathrm{~mm}$, height $900 \mathrm{~mm}$, material FRP, inside filled with GAC 28 litres.

- filtered water tank: 180 litres, material FRP

- reverse osmosis system: includes $3 \mu \mathrm{m}$ prefilter, high pressure pump (50 L/min), RO membrane (Dow Filmtec BW30-4040).

\section{Results and discussion}

Table 5 shows all test results of the pilot plant units. Ceramic membrane filtration system was mainly used to remove suspended solids from the waste streams, and to maintain a

Table 3 Sampling points and water quality analysis for pilot plant tests

\begin{tabular}{|c|c|c|c|c|c|}
\hline & $\begin{array}{c}\text { Equalization } \\
\text { tank outlet }\end{array}$ & $\begin{array}{c}\text { Reaction tank } \\
\text { outlet }\end{array}$ & $\begin{array}{l}\text { Ceramic membrane } \\
\text { filtration system outlet }\end{array}$ & $\begin{array}{l}\text { Activated carbon } \\
\text { filter outlet }\end{array}$ & $\begin{array}{c}\text { Reverse osmosis } \\
\text { system outlet }\end{array}$ \\
\hline $\mathrm{pH}$ & $2 / D$ & $2 / D$ & $2 / D$ & $2 / D$ & $2 / D$ \\
\hline Cond. & $2 / D$ & & $2 / D$ & $2 / D$ & $2 / D$ \\
\hline TDS & $2 / D$ & & $2 / D$ & $2 / D$ & $2 / D$ \\
\hline $\mathrm{H}_{2} \mathrm{O}_{2}$ & $2 / D$ & & $2 / D$ & $2 / D$ & $2 / D$ \\
\hline TOC & $2 / D$ & & $2 / D$ & $2 / D$ & $2 / \mathrm{D}$ \\
\hline $\mathrm{SiO}_{2}$ & $2 / D$ & & $2 / D$ & & $2 / D$ \\
\hline TSS $^{2}$ & $2 / \mathrm{W}$ & & $2 / \mathrm{W}$ & & $2 / \mathrm{W}$ \\
\hline $\mathrm{Al}$ & $2 / \mathrm{W}$ & & & & $2 / \mathrm{W}$ \\
\hline W & $2 / \mathrm{W}$ & & & & $2 / \mathrm{W}$ \\
\hline
\end{tabular}

Note: $2 / \mathrm{D}$ : Twice a day sampling, 2/W: Twice a week sampling

Table 4 Analytical methods, instruments and measuring methods for water quality

\begin{tabular}{ccc}
\hline Items & Analytical methods \& instruments & Measuring methods \\
\hline $\mathrm{pH}$ & Orion 210A & On site \\
$\mathrm{Cond}$. & Ultra meter 4PCE & On site \\
$\mathrm{TDS}$ & Ultra meter 4PCE & On site \\
$\mathrm{SiO}_{2}$ & Hach DR 2010 & On site \\
$\mathrm{TOC}^{\mathrm{H}}$ & Anatel A-2000 & On site \\
$\mathrm{H}_{2} \mathrm{O}_{2}$ & Hach DR 2010 & On site \\
$\mathrm{TSS}_{\mathrm{Al}}$ & NIEA W210.55 & Laboratory \\
$\mathrm{W}$ & ICP-MS & Laboratory \\
& ICP-AES & Laboratory \\
\hline
\end{tabular}


Table 5 Test results of pilot plant units

\begin{tabular}{ccccc}
\hline Items & $\begin{array}{c}\text { Equalization tank } \\
\text { outlet }\end{array}$ & $\begin{array}{c}\text { Ceramic membrane } \\
\text { filtration system outlet }\end{array}$ & $\begin{array}{c}\text { Activated carbon } \\
\text { filter outlet }\end{array}$ & $\begin{array}{c}\text { Reverse Osmosis } \\
\text { system outlet }\end{array}$ \\
\hline $\mathrm{pH}$ & $9.1-10.2$ & $3.5-5.0$ & $5.0-7.5$ & $5.3-7.4$ \\
$\mathrm{Cond}(\mu \mathrm{s} / \mathrm{cm})$ & $120-181$ & $200-399$ & $207-370$ & $5.1-12.6$ \\
$\mathrm{TOC}(\mathrm{mg} / \mathrm{L})$ & $1.9-5.8$ & $1.3-4.0$ & $0.5-1.7$ & $0.1-0.4$ \\
$\mathrm{SiO}(\mathrm{mg} / \mathrm{L})$ & $90-224$ & $90-162$ & $90-162$ & $3.0-7.8$ \\
$\mathrm{TSS}(\mathrm{mg} / \mathrm{L})$ & $2.2-7.1$ & $\mathrm{ND}$ & - & $\mathrm{ND}$ \\
$\mathrm{H}_{2} \mathrm{O}_{2}(\mathrm{mg} / \mathrm{L})$ & $10-40$ & $10-40$ & $0.1-0.9$ & - \\
$\mathrm{TDS}(\mathrm{mg} / \mathrm{L})$ & $92-119$ & $217-300$ & $181-250$ & $3.2-7.5$ \\
$\mathrm{Al}(\mu \mathrm{g} / \mathrm{L})$ & $1,300-11,800$ & - & - & $0.1-0.13$ \\
$\mathrm{~W}(\mu \mathrm{g} / \mathrm{L})$ & $2,800-6,000$ & - & - & $0.14-1$ \\
\hline
\end{tabular}

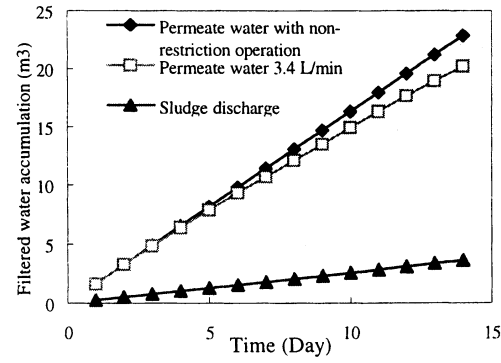

Figure 4 The filtered water accumulation and sludge discharge of ceramic membrane filtration system

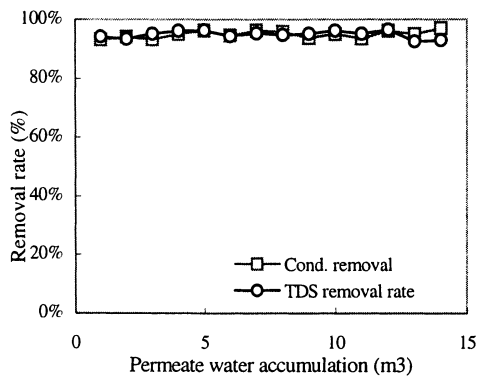

Figure 6 Conductivity and TDS removal rates of RO system

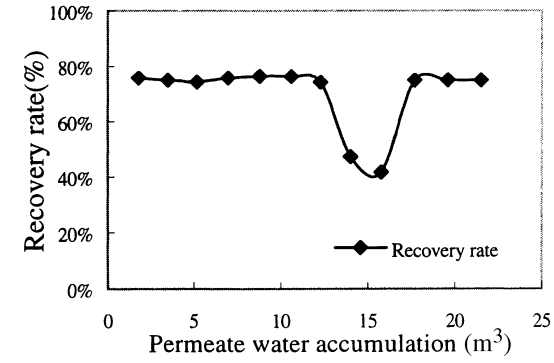

Figure 5 The recovery rate of RO system

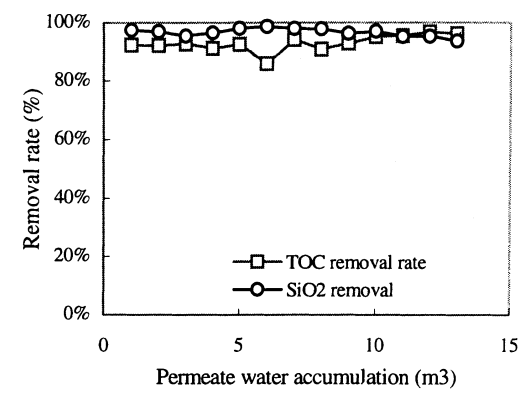

Figure $7 \mathrm{TOC}$ and $\mathrm{SiO}_{2}$ removal rates of $\mathrm{RO}$ system

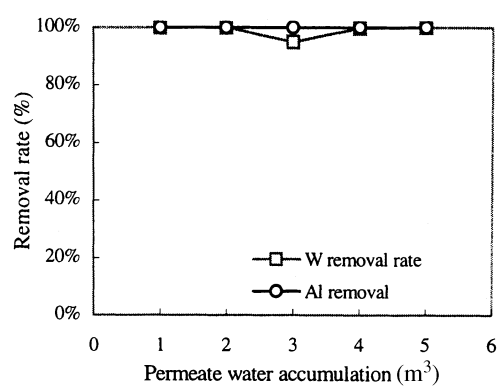

Figure $8 \mathrm{~W}$ and $\mathrm{Al}$ removal rates of $\mathrm{RO}$ system

good operating condition for the down stream systems. The results of pilot plant tests indicated that the recovery rate of ceramic filtration reached $84 \%$ as shown in Figure 4 . Activated carbon adsorption was mainly applied to remove oxidant $\left(\mathrm{H}_{2} \mathrm{O}_{2}\right)$ and organic contaminants (TOC) to avoid attacking or fouling of RO membranes. Reverse osmosis was 
commonly used for removing heavy metals (Al, W) and all ions that contribute to conductivity or total dissolved solids (TDS) and silicate $\left(\mathrm{SiO}_{2}\right)$.

The permeate water of RO system reached $75 \%$ (Fig. 5) and can be recovered to the UPW system for making up; a sudden drop in recovery rate resulted from the fouling of RO membranes, but it was recovered after a chemical cleaning. The other $25 \%$ of concentrate water still can be reused for activated carbon filter backwash, cooling tower make up, scrubber washing, and general rinse water uses. Figures 6, 7 and 8 show the removal rates of conductivity, TDS, TOC, $\mathrm{SiO}_{2}, \mathrm{~W}$ and $\mathrm{Al}$, respectively.

From the operation conditions and test results of the pilot plant, the performance data were scaled up for an actual semiconductor plant with $720 \mathrm{~m}^{3} / \mathrm{d}$ CMP wastewater to estimate the operation cost. Because the ceramic membrane filtration system was getting $84 \%$ recovery rate, the total reclaimed water was about $600 \mathrm{~m}^{3}$ per day. Since the concentrate water from the RO system still can be reused for rinsing purpose, the estimated recovery rate for RO system can be $100 \%$. The running cost of CMP wastewater reclamation is estimated to be NT $\$ 43 / \mathrm{m}^{3}$ as shown in Table 6 .

Table 7 compares the operation costs of this pilot plant to that of the conventional chemical clarification system including advanced treatment, using CMP wastewater of the same characteristics. The operation cost of ceramic membrane filtration system was found to be less than the conventional chemical clarification system, and needs to be widely recommended. Using systems like this model would not only save the consumption of tap water, but would also increase the recovery rate of UPW system rinse water from 50\%-70\% up to

Table 6 Operation cost estimation for CMP wastewater reclamation

\section{Items of expense}

$\operatorname{Cost}(\mathbf{N T} \$ \mathbf{d a y})$

Chemicals

(A) $98 \% \mathrm{H}_{2} \mathrm{SO}_{4}(600 \mathrm{ppm} @ \mathrm{NT} \$ 3 / \mathrm{Kg}) \quad 12,960$

(B) Polymer (16 ppm @ NT\$200/Kg) 2,340

2. Electricity @ NT\$2.5/Kwh

3. RO membrane replacement

3,600

$\begin{array}{lr}\text { 4. Maintenance charge } & 2,917\end{array}$

5. Labor cost 3,333

Overall operation cost $\quad 25,781$

Operation cost per $\mathrm{m}^{3} \quad \mathrm{NT} \$ 43 / \mathrm{m}^{3}$

1. The above cost excludes equipment depreciation fee, sludge dewatering and disposal fee, and the cost of ceramic membrane replacement. (Ceramic membrane has a 10 years service life)

2. RO membrane replacement frequency is calculated based on three years continuous operation.

3. Maintenance fee includes consumable and spare parts, chemicals and labor for ceramic and RO membrane cleaning.

Table 7 Reclaim or treatment operation cost analysis for CMP wastewater

\begin{tabular}{lll}
\hline Cost & Reclamation of CMP wastewater & Treatment of CMP wastewater \\
\hline Basic operation cost & $\mathrm{NT} \$ 43 / \mathrm{m}^{3}$ & $\mathrm{NT} \$ 24-36 / \mathrm{m}^{3} \mathrm{a}$ \\
Tap water cost & not required & $\mathrm{NT} \$ 12.5 / \mathrm{m}^{3}$ \\
Recovery and reuse expense & Water quality has been reached & Need further treatment fee \\
Water usage royalty and & & $\mathrm{NT} \$ 15-25 / \mathrm{m}^{3} \mathrm{~b}$ \\
wastewater effluent fee & not required & $\mathrm{NT} \$ 6-12.5 / \mathrm{m}^{3} \mathrm{c}$ \\
Overall estimated operation cost & $<\mathrm{NT} \$ 43 / \mathrm{m}^{3}$ & $\mathrm{NT} \$ 57.5-86 / \mathrm{m}^{3}$
\end{tabular}

a In the semiconductor industry, the operation cost per each cubic metre of wastewater is based on Chinese Technical Service Institute and actual system operation. The unit cost includes chemical purchasing,

electricity, maintenance, labors, sludge treatment and industrial park wastewater management fee.

$\mathrm{b}$ In semiconductor industry, the operation cost per each cubic metre of ultra pure water would be

30-50 NT\$ according to engineering experience.

${ }^{c}$ Water usage royalty fee and wastewater effluent fee assume to be the same as city water. 
$84 \%$. This rate is higher than the $80 \%$ recovery rate designated by the Industrial Science Park authority toward all established semiconductor companies. According to the operation conditions and the results from the pilot test, it will cost around NT $\$ 43$ per cubic metre wastewater, given a recovery capacity of $600 \mathrm{~m}^{3} /$ day of CMP wastewater. If conventional chemical clarification system is applied and additional advanced treatment units added to raise the water quality to a level similar to reclaimed water from the pilot plant, the estimated treatment operation cost will be between $57.5-86 \mathrm{NT} \$ / \mathrm{m}^{3}$ which is much higher than the reclaim operation cost.

\section{Conclusion}

The outcome of the pilot test indicates that using the ceramic membrane filtration system combined with an activated carbon filter and reverse osmosis unit is able to efficiently reclaim CMP wastewater and significantly improve the recovery rate up to $84 \%$. The quality of reclaimed water produced is able to meet the water quality required for use in the UPW system. Due to the diversity of CMP processes, and varying chemical additions, the characteristics of the wastewater from one CMP waste stream can be considerably different to the characteristics of wastewater from another CMP waste stream. Oxide CMP and metal CMP are commonly applied nowadays, and to treat these different CMP waste streams, correct acid and polymer dosage has to be defined to achieve an acceptable clarification effect. Pilot plant tests, such as those conducted in this study, would provide valuable data for establishing better operation conditions, and for reducing the operation cost. The highly concentrated CMP slurry and rinse wastewater should be collected separately. The highly concentrated CMP slurry can be recovered by using dissolved air flotation process, and reused as abrasive agent or other applications. The rinse wastewater should be discharged into the ceramic membrane filtration system, because by lowering the level of suspended solids in wastewater the service cycle of ceramic membrane filtration can be increased, and reduces chemical consumption as well as the operation cost.

\section{References}

Golden J.H., Small R., Pagan L., Shang C. and Raghavan S. (2000). Evaluating and treating CMP wastewater. Semiconductor International, October, 1-12.

Lin J.B., Lei T.T., Wen S.B., Tu J.W. and Chang J.F. (1999). Using column pressure release flatation to treat CMP wastewater. Proc. of the 24th Wastewater Treatment Conference in Taiwan (in Chinese), 851-856.

Mettson M.J., Dobson R.L., Glenn R.W., Kukunoor N.S., Waits W.H. and Clayfield E.J. (1995). Electrocoagulation and separation of aqueous suspensions of ultrafine particles. Colloids and Surface, A104, 101-109.

Raghavan S. (1999). Treatments strategies for wastes from CMP operations. Proc. of International Conference for Wafer Rinsing, Water Reclamation and Environment, Technology for Semiconductor Manufacturing, 1-18.

Yang G.C.C. and Yang T.Y. (2002). A preliminary study on water reclamation from CMP wastewater using a novel treatment module. Journal of the Chinese Institute of Environmental Engineering, 12(3) (in press). 